\title{
四配位共有結合性物質の液体の圧力誘起構造変化
}

Pressure-Induced Structural Changes in Liquids of Tetrahedrally Bonded Materials

\section{服部 高典}

\author{
Takanori HATTORI
}

\begin{abstract}
We investigate pressure-induced structural changes in liquids of tetrahedrally bonded materials by synchrotron $\mathrm{x}$-ray diffraction. The liquids show various structural changes, depending on their ionic characters in the chemical bonds. The liquids with a small ionic character, such as GaSb, InSb, and InAs, show continuous structural changes over a wide pressure region of about $20 \mathrm{GPa}$. In contrast, those with a large ionic character, such as $\mathrm{CdTe}$ and AgI, show drastic structural changes within a narrow pressure region of about $2 \mathrm{GPa}$. We discuss the effect of the ionicity on the pressure-induced structural changes in the liquids and compare the effect with that in the crystalline phases.

[liquid, tetrahedrally bonded materials, ionicity, pressure-induced structural change, synchrotron radiation.]
\end{abstract}

\section{1. はじめに}

\section{1 液体の圧力誘起構造変化}

液体の圧力誘起構造変化というと，「そもそも液 体に構造などあるのか?」と不思議に思うかも知れ ない。液体を微視的に見ると，その原子配列は，時 間的，空間的に変動しており，結晶に見られるよう な長距離秩序は存在しない。しかしながら，ある原 子から周りの原子を見た場合, “一定の距離” の所 に“一定の個数”の原子が存在するのが多く見られ る。このように, 液体状態においても, 最近接原子 間距離の数倍までの範囲では, 原子の配列に秩序 (短距離秩序) が見られる。我々は，これを液体の 構造と呼ぶ。

教科書に載っている温度圧力相図をみると, 結晶 相には多くの高圧相が書かれている。一方, 液体相 の部分には, “Liquid”としか書かれていない。液体 相においても，はっきりとした高圧安定相を定義で きないとしても, 高圧下においてその構造は変わる はずである。また, その構造変化は, 液体の局所構 造が原子間距離や角度相関に広い分布をもつことを 反映して, 結晶のものとは異なることが予想され, 大変興味深い。本稿では, 我々が最近行ってきた四 配位共有結合性物質の液体の圧力誘起構造変化の研
究を紹介する。

\section{2 四配位共有結合性物質}

四配位共有結合性物質とは， $s p^{3}$ 共有結合を基に した四配位の局所構造を持つ物質であり，IVB 族元 素, III-V 化合物, II-VI 化合物に多く見られる。 IVB 族元素扔よび III-V 化合物は，融解すると金属 化し体積が小さくなる。このため，その融解曲線は 負の傾きを持つことが知られている。しかしその局 所構造は，液体金属にもかかわらず微視的に異方的 であり, 融解後も共有結合性の一部を残していると 考えられている。また，その局所構造として，Si の高圧結晶相である $\beta$-tin 型構造（6 配位をもつ金 属相）と似たものであることが知られている[1-3]。 一方, II-VI 化合物は, 融解後む半導体である。こ れらの物質はともに, 融解後も共有結合性を持つと いう特徴を持っている。一般に, 物質に圧力をかけ ると, 電子密度の増加に伴い, 化学結合がより金属 結合的になる。これらの共有結合を持った液体も， 圧力誘起の化学結合性の変化を通じて, 液体の構造 が大きく変化することが期待される。これまでの研 究から, 液体 Si は約 7 $14 \mathrm{GPa}$ の間で急激に構造 が変化し[4], 液体 Ge は, 広い压力範囲にわたって 構造が連続的に変化することが知られている $[5,6] 。$

干223-8522 神奈川県横浜市港北区日吉 3-14-1 慶應義塾大学理工学部 物理学科

Faculty of Science and Technology, Keio University, 3-14-1 Hiyoshi, Kohoku-ku, Yokohama 223-8522

Electronic address: takanori@phys.keio.ac.jp 
しかしながら，その構造変化の詳細，すなわちどの ような構造へ, どのような圧力範囲で変化するかは よくわかっていない。これらを明らかにするために は, 精密な液体の構造デー夕を基に, 構造モデルと の定量的な比較を行う必要がある。本研究の第一の 目的は, これらの過程を通して, 共有結合を持つ液 体の圧力誘起構造変化を定量的に議論することであ る。

\section{3 圧力誘起構造変化に及ぼすイオン性の影響}

III-V 化合物, II-VI 化合物などの異なる 2 種類の 元素からなる物質は，その化学結合として，共有結 合性に加えイオン結合性を持つ。その成分の割合は, 2 種類の元素の組み合わせによって異なり, Phillips のイオン性の定義[7] で $f_{i}=0$ から $f_{i}=0.785$ の值を 持っている。これらの物質は, これまでの結晶相に おける研究から，イオン性によって異なる圧力誘起 構造シークエンスを示すことが知られている $[8,9]$ (Fig. 1)。すなわち，イオン性の小さな物質は, diamond/zincblende 構造 $\rightarrow \beta$-tin 構造 $\rightarrow$ 稠密な構造 （bcc, fcc, hcp 構造等）と相転移し，イオン性の大き な物質は, zincblende 構造 $\rightarrow$ rocksalt 構造 $\rightarrow$ 斜方 $\mathrm{Cmcm}$ 構造 $\rightarrow \mathrm{CsCl}$ 構造と相転移する。一方, 液体 相においても結晶相と似た局所構造が実現されるこ とが予想されるため, その圧力誘起構造変化もイオ ン性の影響を受けることが期待される。本研究の第

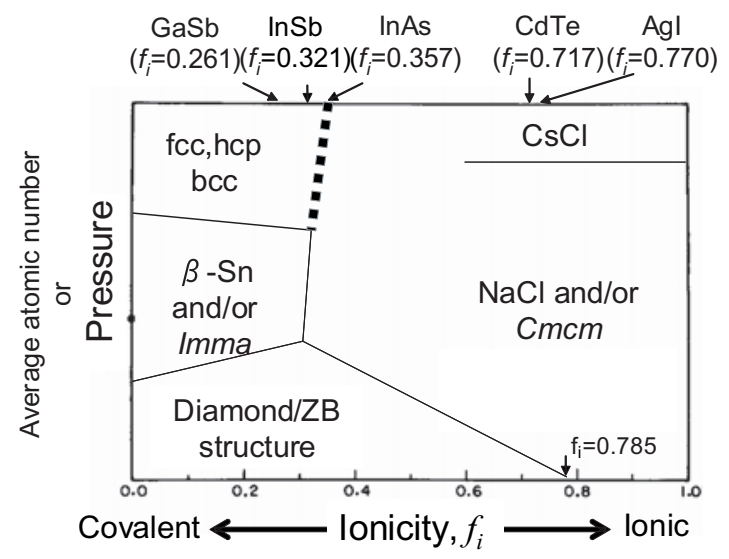

Fig. 1. Ionicity dependence of the pressure-induced structural changes in the crystals of tetrahedrally bonded materials. Ionicity is based on Phillips scale[7]. The materials with the large average atomic number show crystal structures similar to those realized in the materials with smaller atomic numbers at lower pressures. Therefore, the vertical axis represents an average atomic number, as well as the pressure.
二の目的は，その影響を調へ，結晶相における振る 舞いとの違いを明らかにすることである。以上の目 的を踏まえ，我々はイオン性の異なる5つの四配位 共有結合性物質（GaSb, InSb, InAs, CdTe, AgI）の 液体の圧力誘起構造変化を約 $20 \mathrm{GPa}$ まで調べた。

\section{2. 実験}

実験は，マルチアンビル高圧発生装置を用いた X 線回折法により行った。測定は，放射光施設の高圧 ビームライン（PF-AR の NE-5C, PF の BL14C2, SPring-8 の BL04B1, BL22XU）で行った。実験方法 の詳細は論文 $[10-12]$ 参照。

\section{3. 液体の圧力誘起構造変化}

実験を行った全ての物質において，加圧に伴う液 体の構造変化が見られた。その変化は，それぞれの 物質の持つイオン性に大きく依存し，それらは $2 つ$ のグループに大別できることがわかった。以下に， 各グループの圧力誘起構造変化の詳細を示す。

\section{1 小さなイオン性をもつ液体の圧力誘起構造変 化}

\subsection{1 $S(Q), g(r)$ および配位数の圧力変化}

比較的小さなイオン性 $\left(f_{i}<0.36\right)$ を持つ物質 （GaSb, InSb, InAs）は，対応する圧力は違うものの よく似た構造変化をすることがわかった。その代表 例として, 液体 $\mathrm{GaSb}$ の圧力誘起構造変化[12] を紹 介する。実験から得られた液体 $\mathrm{GaSb}$ の構造因子 $S(Q)$ および二体分布関数 $g(r)$ の圧力変化を Fig. 2, 3 に示す。

$S(Q)$ の圧力変化を見ると, 加圧に伴い第一ピー クが高 $Q$ 側にシフトし，高さが大きくなるのが見ら れる。第二，第三ピークに扔いては，高さ位置とも に大きな変化は見られない。また，第一ピークの高 波数側に位置する “局所構造の異方性”を反映した ハンプ（ $\left.Q \sim 3.2 \AA^{-1}\right)$ は，加圧とともに小さくなる。 液体が局所構造の変化を伴わずに，ただ単に一様に 収縮した場合， $S(Q)$ は高 $Q$ 側に一様に拡大される のみで，その形状は変わらないはずである。液体 $\mathrm{GaSb}$ に打ける $S(Q)$ の形状の変化は, 液体が一様 に収縮せず，加圧とともに局所構造が変化すること を示している。

$g(r)$ の圧力変化からも同様のことが言える。 $g(r)$ 
の第二，第三ピークは，加圧とともに低 $r$ 側にシフ トし，高さも大きくなる。一方，第一ピークの位置 （最近接原子間距離に対応）は，体積収縮にも関わ らずほとんど変わらない。また，第一ピークの高 $r$ 側にあるハンプは，加圧に伴い小さくなっている。 これらの結果は, 液体の局所構造が加圧とともに変 化することを支持している。

局所構造の変化を確かめるために, 動径分布関数 $\left(=4 \pi r^{2} \rho_{0} g(r), \rho_{0}\right.$ : 平均数密度 $)$ 加ら計算した平均

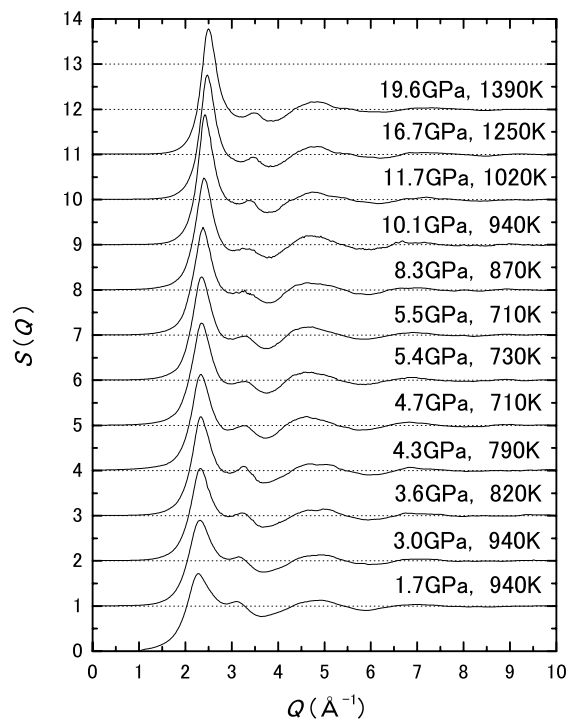

Fig. 2. $S(Q)$ of liquid $\mathrm{GaSb}$ at high pressures[12].

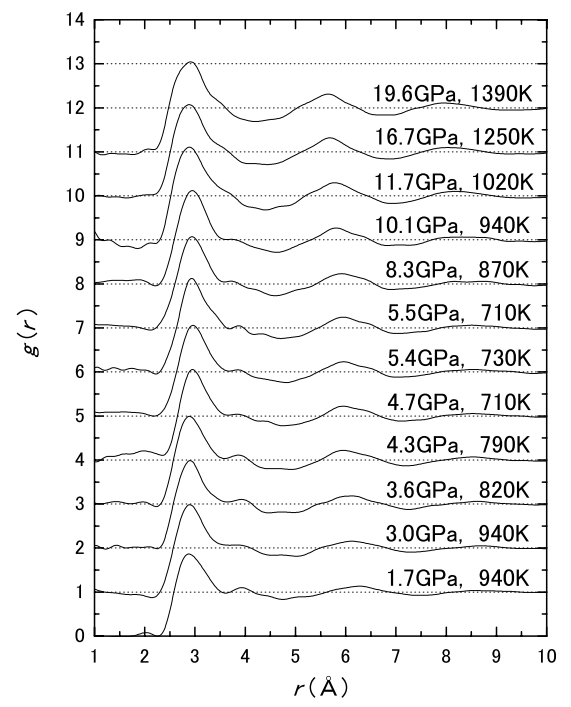

Fig. 3. $g(r)$ of liquid $\mathrm{GaSb}$ at high pressures[12].
配位数 CN の圧力変化を Table 1 に示す。常圧付近 においてその配位数は，共有結合を持った異方的な 局所構造の存在を反映し，単純液体のもの $(\mathrm{CN}=10 \sim 11[13] ）$ と比べてずいぶん小さい。加 圧に伴い，配位数は連続的に増大する。このことは, 液体の局所構造が, 配位数のより大きなものへと徐々 に変わっていくことを示している。

\subsection{2 局所構造の推定}

液体 $\mathrm{GaSb}$ の局所構造を推定するために, 実験か ら得られた $g(r)$ を, 結晶構造を基に simulateした $g(r)$ と比較した。 simulationに打いて，液体の原子 配置に摇らぎがあること及びその摇らぎの大きさが 原子間距離に伴って増大することを考慮に入れ，結 晶に打ける原子間距離に分布を持たせ，その分布は 遠い原子ほど大きくなるようにした（歪んだ結晶モ

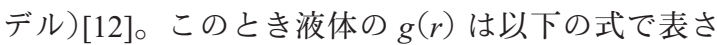
れる。

$$
\begin{aligned}
& g(r)=\sum_{j=1}^{N} \frac{A_{j}}{\sqrt{2 \pi} \sigma_{j}} e^{-\frac{\left(r-r_{j}\right)^{2}}{2 \sigma_{j}}} \\
& A_{j}=\frac{1}{4 \pi \rho_{0}\left(r_{j}^{2}+\sigma_{j}^{2}\right)} \\
& \sigma_{j}=\left(\frac{r_{j}}{r_{1}}\right)^{t} \sigma_{1}
\end{aligned}
$$

ここで, $N$ は原子数, $r_{j}$ は $j$ 番目の原子までの距離, $\sigma_{j}$ は $j$ 番目の原子に対する摇らぎ， $A_{j}$ は規格化因子, $t$ は短距離秩序の decay 因子である。四配位共有結 合性物質においてこれまでに報告されている結晶構 造（高圧相の構造も含む）を基に $g(r)$ の simulation を行った。その結果, どの構造から simulateした $g(r)$ を用いても実験の $g(r)$ をうまく再現できなかっ

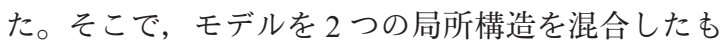
の（二種混合モデル）に拡張した。このモデルは, 高圧下の融点極大現象を説明するために，その昔 Klement[14]によって提唱され, Rapoport[15]によっ て定式化された。二種混合は, Gibbs の自由エネル ギーにおいて，二種類の局所構造を共存させること による内部エネルギーの上昇を混合エントロピー項 で補って余りあるときに実現する。この状態は特に 液体のような，局所構造に柔軟性があり，かつ高温 条件にある場合は実現しやすいと考えられる。この モデルに基づくと，2つの局所構造 $\mathrm{A}, \mathrm{B}$ を持つ液 体の $g(r)$ を以下のように表すことができる（詳細 は文献 [12] 参照)。

$$
g(r)=(1-x) g_{\mathrm{A}}(r)+x g_{\mathrm{B}}(r)
$$


ここで $x$ は高圧局所構造 $\mathrm{B}$ の割合である。今回 の simulation では, 2 つの局所構造の体積, 原子間 距離の分布に関する変数は共通とした。このとき, simulation に打ける変数は全部で $4 つ\left(\sigma_{1}, r_{1}, t, x\right)$ となる。

実験で得られた $g(r)$ を前述のモデルで fitした結 果の典型例を Fig. 4 に示す。 2 つの局所構造として $\beta$-tin 構造と bcc 構造を用いたときのみ良い一致が 見られた。たった 4 つの変数で simulationしたにも 関わらず，各圧力点における $g(r)$ を，低 $r$ 域から 高 $r$ 域まで，高い精度で再現することができた（残

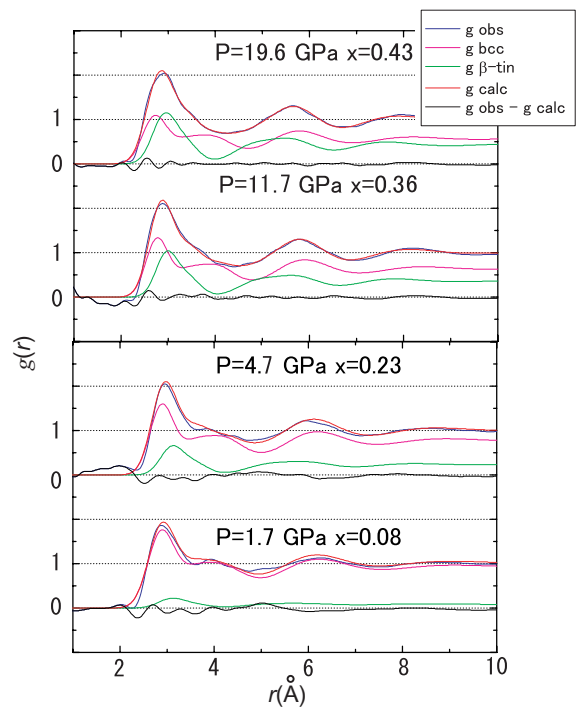

Fig. 4. Typical results of the analysis of the experimental $g(r)$ by a set of a distorted crystalline model and a two species model. The fraction of the bcc-like local structure is presented by $x$.

Table 1. Average coordination number $\mathrm{CN}$ and the fraction of the denser form $(x)$ determined by a set of models (see Sec. 3.1.2).

\begin{tabular}{rrr}
\hline \hline$P(\mathrm{GPa})$ & average $\mathrm{CN}$ & $x$ \\
\hline $1.7(1)$ & $6.1(5)$ & $0.08(1)$ \\
$3.0(1)$ & $6.4(5)$ & $0.14(1)$ \\
$3.6(1)$ & $6.3(5)$ & $0.15(1)$ \\
$4.3(1)$ & $6.9(5)$ & $0.18(1)$ \\
$4.7(1)$ & $6.8(5)$ & $0.23(1)$ \\
$5.4(1)$ & $6.6(5)$ & $0.26(1)$ \\
$5.5(1)$ & $6.6(5)$ & $0.27(1)$ \\
$8.3(1)$ & $7.9(5)$ & $0.29(1)$ \\
$10.1(1)$ & $8.3(5)$ & $0.34(1)$ \\
$11.7(2)$ & $9.0(5)$ & $0.36(1)$ \\
$16.7(3)$ & $9.1(5)$ & $0.40(1)$ \\
$19.6(3)$ & $10.0(5)$ & $0.43(1)$ \\
\hline \hline
\end{tabular}

差は 5\%以内）。高圧局所構造の割合（Table 1）は, 結晶の場合とは異なり，加圧に伴って“徐々に”上 昇することがわかる。また，液体中では 2 つの局所 構造が広い圧力範囲 $(\Delta P \sim 20 \mathrm{GPa})$ にわたって “共存”していることがわかる。

ここで 2 つの局所構造として $\beta$-tin 構造と bcc 構 造と述べたが，最近の液体 InSb の結果 [16] から, 高圧型局所構造として, bcc 構造というょりむしろ “ $\beta$-tin 構造と bcc 構造の $1: 1$ の混ぜ物”で表され る単一の局所構造がより妥当であることがわかった。 この構造の本性は良くわかっていないが，以下これ を“ $1 / 2 \beta$-tin $+1 / 2$ bcc” 構造と便宜上表現する。この とき, 高圧局所構造の割合 $(y)$ は，新しい高圧局 所構造を導入する前の值 $(x)$ に比べて 2 倍になる。

\subsection{3 局所構造の温度圧力変化}

Rapoport モデル[15] において, 高圧局所構造の割 合 $y$ は温度・圧力と次の関係式で結びついている。

$$
\begin{aligned}
& k_{\mathrm{B}} T \ln \frac{y}{1-y}+(1-2 y) \omega=\Delta \mu^{0} \\
& \Delta \mu^{0}=\Delta \varepsilon^{0}-T \Delta S^{0}+P \Delta V^{0}
\end{aligned}
$$

ここで, $\Delta V^{0}, \Delta \varepsilon^{0}, \Delta S^{0}$ は2 つの局所構造の体積差, 内部エネルギー差，エントロピー差であり， $\omega$ は隣 り合った局所構造において同種ぺアを異種ペアで取 り替えたときに上昇する内部エネルギーである。液 体 GaSb の圧力誘起構造変化が Rapoport モデルで説 明できるかどうかを確かめるために，解析によって 得られた高圧局所構造の割合 $(y)$ を上式で fit した (Fig. 5)。その結果，広い温度圧力にわたって，高 圧局所構造の割合を再現することができた。この fittingによって得られたモデルの変数 $\left(\Delta V^{\circ}=\right.$ $4.3 \AA^{3}$ /atom, $\Delta \varepsilon^{0}=8.1 \times 10^{-21} \mathrm{~J} /$ atom, $\Delta S^{0}=4.2 \times$ $10^{-23} \mathrm{~J} / \mathrm{K}$ per atom, $\omega=-3.5 \times 10^{-21} \mathrm{~J} /$ atom）を基に, 高温高圧下における高圧局所構造の割合を推定した (Fig. 6)。これを見ると，相図上ではただ単に “Liquid”之書かれている液体相は，われわれの知ら ないところで密かに結晶性固体に見られるような構 造変化をしていることがわかる。さらに，決定され たモデルの変数から, 液-液臨界点の温度圧力值を 推定できる [17]。その温度圧力は, $\left(P_{\mathrm{c}}, T_{\mathrm{c}}\right)$ ～ （3.1 GPa, - $128 \mathrm{~K})$ となり, 融解曲線より下に位置 することがわかる（ $T_{\mathrm{c}}$ が負となるのでそもそも存 在し得ない)。臨界点が融解曲線の上に顔を出した ときに, 液体-液体一次相転移は起こりうる。従っ て，液体 $\mathrm{GaSb}$ においては，（少なくとも今回考え 
た低圧及び高圧局所構造間では）液体－液体一次相 転移は実現しないと考えられる。

\section{2 大きなイオン性をもつ液体の構造変化}

\subsection{1 $S(Q), g(r)$ および配位数の圧力変化}

比較的大きなイオン性 $\left(f_{i}>0.71\right)$ を持つ物質 （CdTe, $\mathrm{AgI}$ ）は，小さなイオン性をもつ物質とは異 なる振る舞いを示す。その代表例として，液体 $\mathrm{CdTe}$ の圧力誘起構造変化 $[18,19]$ を以下に示す。実 験から得られた液体 $\mathrm{CdTe}$ の構造因子 $S(Q)$, 二体 分布関数 $g(r)$ の圧力変化を Fig. 7, 8 に示す。

約 $1.8 \mathrm{GPa}$ までの加压において, $S(Q)$ はその形 を変えずに高 $Q$ 側へ単調にシフトする。しかしな がら, 約 $3.0 \mathrm{GPa}$ まで加圧すると $S(Q)$ の形が大き く変化し， $Q \sim 2.0 \AA^{-1}$ のピークが消失し, $Q \sim$ $2.3 \AA^{-1}$ に新しくピークが出現する。さらに加圧す

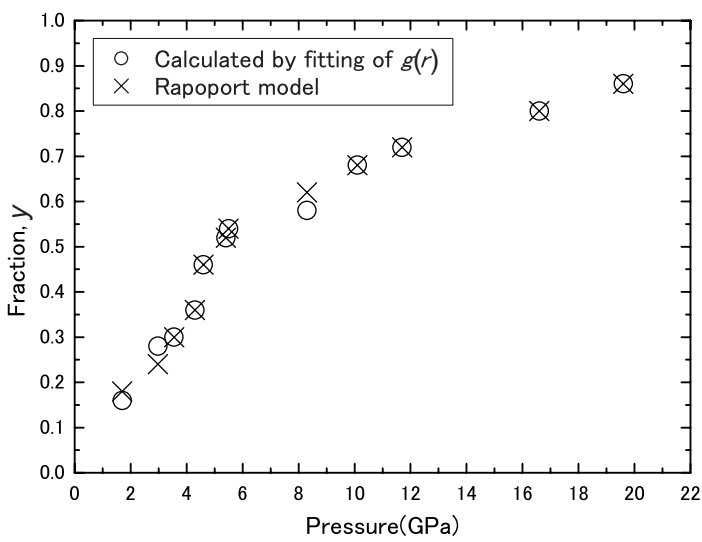

Fig. 5. Results of the fitting of the fraction of the denser form by the Rapport two species model[15].

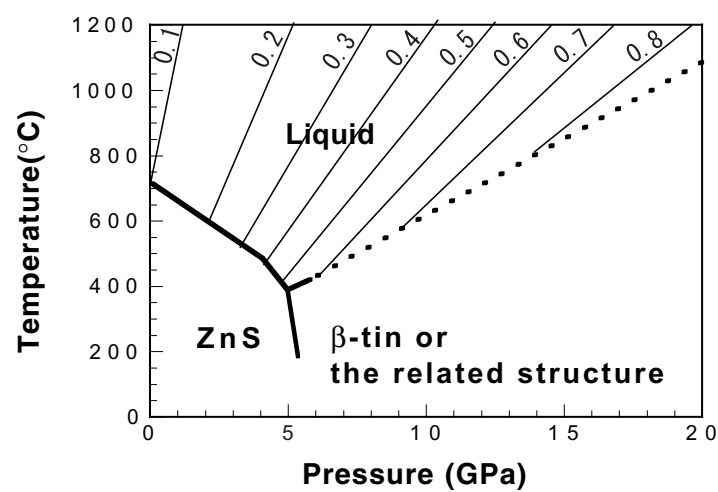

Fig. 6. Pressure and temperature variation of the fraction of the denser local structure $(1 / 2 \beta$-tin $+1 / 2$ bcc $)$ in liquid GaSb.
ると, 新しい $S(Q)$ の形状のまま再び高 $Q$ 側へ, 単 調にシフトする。これらのことは， $1.8 \mathrm{GPa}$ $3.0 \mathrm{GPa}$ の間で液体の構造が急激に変化することを 示しており，その低圧側および高圧側で異なる $2 つ$ の安定な液体構造があることを示している。

急激な構造変化は $g(r)$ の圧力依存性からも示さ れる。すなわち, 約 $1.8 \mathrm{GPa}$ までは $g(r)$ の形状に 顕著な変化は見られないが， $3.0 \mathrm{GPa}$ まで加圧する と，第二ピークが低 $r$ 側にジャンプする。さらに高

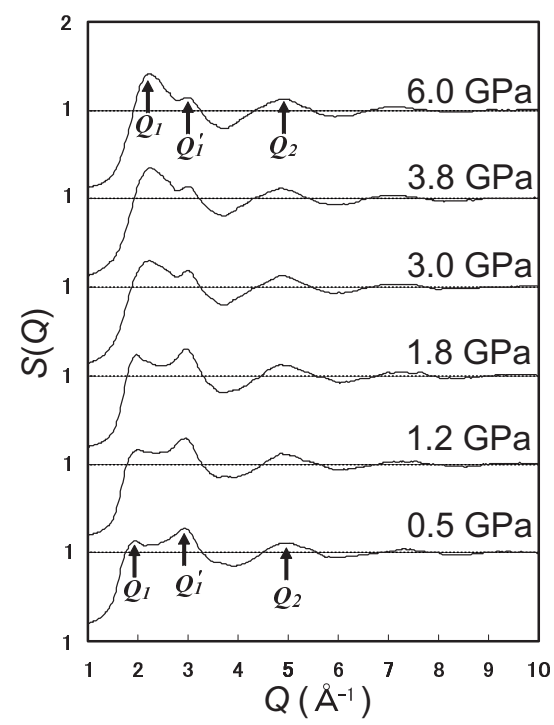

Fig. 7. $S(Q)$ of liquid CdTe at high pressures[18].

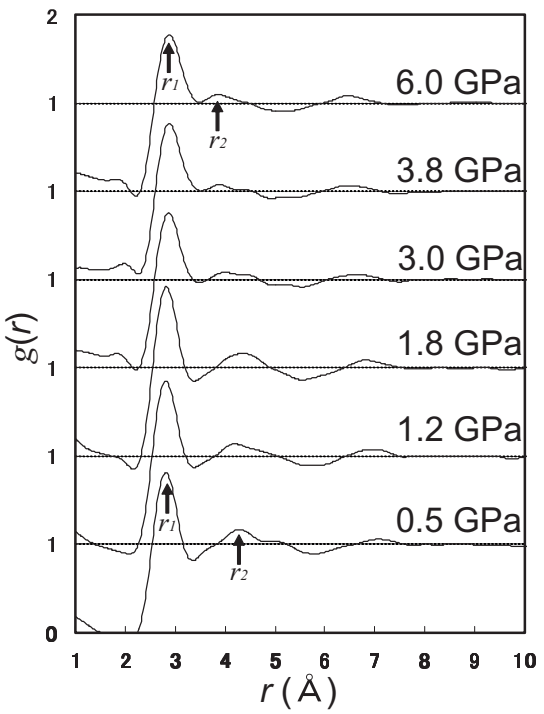

Fig. 8. $g(r)$ of liquid CdTe at high pressures[18]. 
い圧力下では， $g(r)$ の形状に変化は見られない。

局所構造の圧力変化を確かめるために，平均配位 数の圧力変化を Fig. 9 に示す。約 $1.8 \mathrm{GPa}$ 以下では, 配位数は一定であるが，約 $3.0 \mathrm{GPa}$ まで加圧すると， その值は，急激に上昇する。さらに加圧しても配位 数は一定のままである。この結果から, 液体 $\mathrm{CdTe}$ における急激な構造変化は, 配位数の上昇を伴うも のであることがわかる。液体 $\mathrm{CdTe}$ に見られるこれ らの振る舞いは, 構造変化の起こる圧力幅という点 で，前述の液体 $\mathrm{GaSb}$ のものと大きく異なっている。 また，このような狭い圧力範囲で急激な構造変化を する例は，他の液体と比べても大変珍しいものであ る。

\subsection{2 局所構造の推定}

低圧域および高圧域で見られた液体の局所構造を 推定するために，それぞれの圧力域における $S(Q)$ を，これまで構造の調べられているランダム系物質 の $S(Q)$ と比較した。結晶相に扔いて, CdTe は低 圧下 $(P<$ 約 $2.7 \mathrm{GPa})$ で zincblende 構造, 高圧下 $(P>$ 約 $3.6 \mathrm{GPa})$ で rocksalt 構造あるいはそれに関 連した構造をとることが知られている[20]（Fig. 11）。 このことから，低圧液体の局所構造は zincblende 構 造に, 高圧液体の局所構造は rocksalt 構造に似てい ることが予想される。そこで, 低圧液体の $S(Q)$ を zincblende 構造と同じ四配位ネットワーク構造をもっ ているアモルファス $\mathrm{Si}$ の $S(Q)[21]$ と, 高圧液体の $S(Q)$ を液体 $\mathrm{NaCl}$ の $S(Q)[22]$ と比較した（Fig. 10）。 低圧液体の $S(Q)$ は，ピーク位置の比およびピー ク高さの比が，アモルファス $\mathrm{Si}$ のものとよく一致

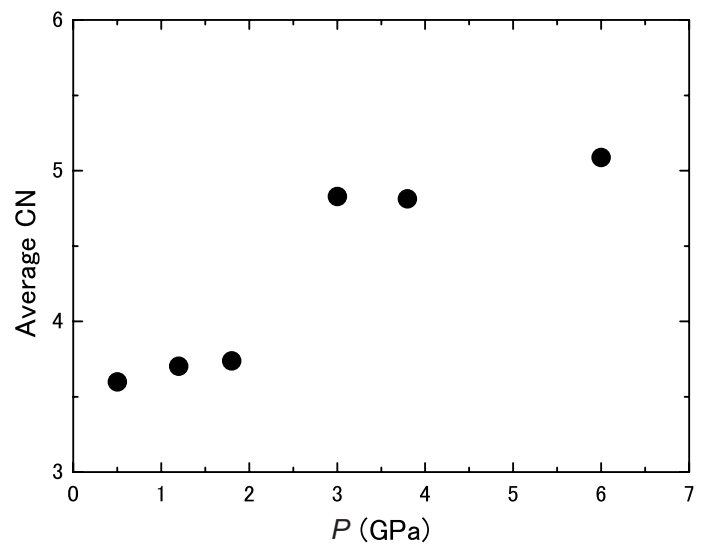

Fig. 9. Pressure dependence of the average coordination number $\mathrm{CN}$ in liquid $\mathrm{CdTe}[19]$.
している（高さの絶対值は一致していないが，これ は液体の方が原子の熱振動が激しいために, $S(Q)$ の振幅がより大きく減衰するためである)。一方, 高压液体の $S(Q)$ 屯, 液体 $\mathrm{NaCl}$ のものと良く一致 していることがわかる。このことから，低圧液体は zincblende に似た局所構造を持ち，高圧液体は rocksalt に似た局所構造を持つことがわかる（液体 $\mathrm{NaCl}$ の局所構造が rocksalt 構造と似ているかどう かは，議論の余地がありますが)。また， $1.8 \mathrm{GPa}$ か ら $3.0 \mathrm{GPa}$ の間で見られた急激な構造変化は, この 両者の間の構造变化によるものであると思われる。

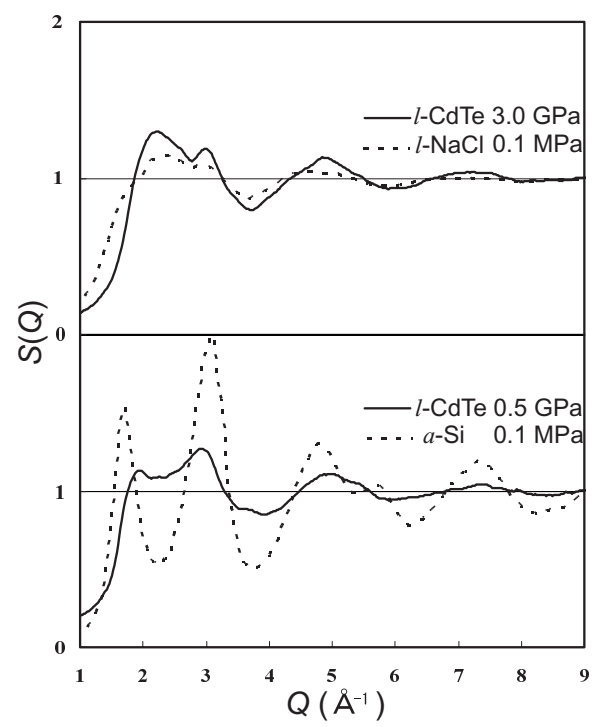

Fig. 10. Comparison of $S(Q)$ of liquid CdTe with those of amorphous $\mathrm{Si}[21]$ and liquid $\mathrm{NaCl}[22]$.

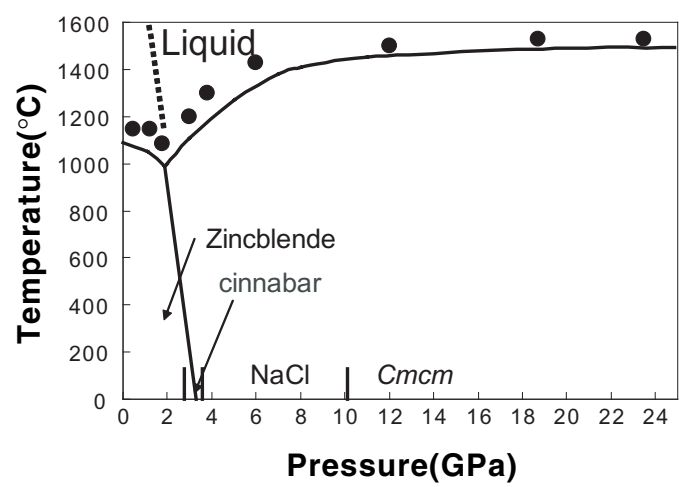

Fig. 11. Phase diagram of CdTe[19]. The hypothetical phase boundary between two liquid forms is also shown. 


\subsection{3 結晶相における圧力誘起構造変化との比較} 今回明らかとなった液体相に打ける構造変化を, これまでにわかっている CdTe の相図上に示す (Fig. 11)。今回発見された液体 CdTe における急激 な圧力誘起構造変化は, 結晶相における zincblenderocksalt 相境界の延長線に近いところで起こること がわかる。このことは, CdTeに扔いて, 結晶, 液 体に関わらず “同じような圧力”で，“同じような 構造変化”をすることを示している。一般の物質で は, 結晶相と液体相とで, 異なる圧力において構造 変化をするのが普通である。このような意味でも液 体 CdTe に抢ける構造変化は，稀な例である。同じ ような変化は液体 AgI にも見られており [23], イオ ン性の大きな四配位共有結合性物質に一般的に起こ るものと考えられる。

\section{4. 液体の圧力誘起構造変化に及ぼすイオン性の影 響}

今回明らかとなった 5 種類の四配位共有結合性物 質の液体における圧力誘起構造変化を, イオン性に 対して示す (Fig. 12)。構造シークエンスはイオン 性によって異なり，イオン性小さいもの $\left(f_{i}<\right.$ 0.36）は， $\beta$-tin 的な局所構造 $\rightarrow$ “ $1 / 2 \beta$-tin $+1 / 2$ bcc” 構造へと変化し，イオン性の大きなもの $\left(f_{i}>\right.$ 0.71）は zincblende 的な局所構造 $\rightarrow$ rocksalt 的な局 所構造へと変化する。また, その構造変化の起こる

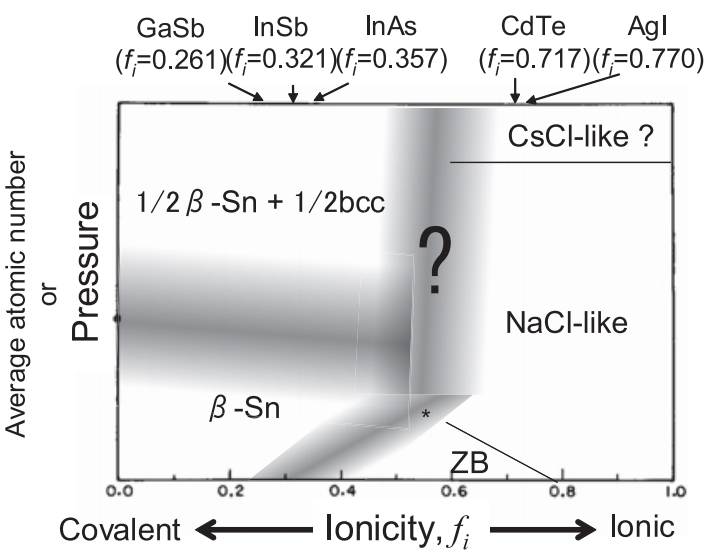

Fig. 12. Ionicity dependence of the pressure-induced structural changes in the liquids of tetrahedrally bonded materials. Ionicity is based on Phillips scale[7]. The vertical axis represents the average atomic number as well as the pressure because of the same reason mentioned in the caption of Fig. 1.
圧力幅を見ると，前者では，約 $20 \mathrm{GPa}$ と広いのに 対し，後者では数 $\mathrm{GPa}$ とかなり狭い。

イオン性による構造のシークエンスの違いは，ど の化学結合（共有結合，イオン結合，金属結合等) によって，構造が安定化されているかに因っている。 すなわち，イオン性の大きな物質においては，2 種 類の化学種を交互にならべることによって静電的に 安定化される rocksalt 型局所構造をとっている。一 方，イオン性の小さい物質については，静電的安定 化というよりむしろ共有結合により安定化される $\beta$-tin や金属結合で安定化される bcc 構造をとって いると考えられる。

イオン性による転移幅の違いは，低圧および高圧 局所構造が共存した時のエネルギー上昇 $\omega$ ，および 両局所構造間の体積差 $\Delta V^{0}$ が深く関係していると考 えられる。Rapoport モデルで示されるように， $\omega / k T$ が大きいとき（つまり，原子の運動エネルギーに対 して異種局所構造の共存に伴うエネルギー上昇が大 きいとき)，液体は低圧および高圧局所構造に相分 離する傾向を示す。また，たとえ相分離しなくとも， 共存が実現する圧力域は, 低圧構造と高圧構造の （仮想的）相境界のごく近傍に限定される（つまり 転移の圧力幅が狭い)。イオン性の異なる2つのグ ループの間で， $\omega$ を比較すると，イオン性の小さな 物質では，低圧および高圧局所構造が金属性を持っ ているため，異種局所構造が隣り合っても，その界 面エネルギーは，それほど大きくないことが予想さ れる。一方，イオン性の大きな物質では，両局所構 造の原子間距離のミスマッチによって引き起こされ る同種原子の接近が，静電エネルギーを上昇させる ために， $\omega$ が大きいことが予想される。また， $\Delta V^{0}$ について考えてみると $\Delta V^{0}$ が大きい場合には（仮想 的）転移圧 $P_{\mathrm{t}}$ を越えて過加圧した場合の構造変化 の駆動力, $\int_{P_{t}}^{P} \Delta V^{0} d P$ がより大きくなる。そのため僅 かな加压によっても, 低圧構造と高圧構造の自由工 ネルギー関係を大きく変化させる。このとき, 狭い 圧力範囲で構造変化が完了する。結晶相扔ける相転 移時の体積変化から類推して, イオン性の小さな物 質における構造変化 $(\beta$-tin $\rightarrow$ “ $1 / 2 \beta$-tin $+1 / 2$ bcc”) では，その体積変化 $\Delta V / V$ は〜 $1 \%$ 之比較的小さい と考えられる。一方，イオン性の大きな物質におけ る構造変化（zincblende $\rightarrow$ rocksalt）では $\Delta V / V$ は 15 $\%$ 以上大変大きいと考えられる。これら 2 つ要 因 $\left(\omega\left\llcorner\Delta V^{\circ}\right)\right.$ のために，イオン性の大きな物質は 狭い圧力範囲で構造変化をするものと推測される。 


\section{5. イオン性が与える影響の結晶相との比較}

今回明らかとなった液体の圧力誘起構造変化のイ オン性による影響（Fig. 12）を，結晶相のもの (Fig. 1) と比べると, その構造シークエンスを左右 する臨界イオン性 $f_{\text {cri }}$ が大きく異なることがわかる。 すなわち結晶相では, $f_{\text {cri }} \sim 0.32$ であるのに対し, 液 体相においては, 少なくとも $f_{\text {cri }}$ は 0.357 以上であ る（最近の我々の液体 InPによる結果から， $f_{\text {cri }}$ はさ らに大きく $f_{\text {cri }}>0.421$ であることがわかっている $[2$ 4]）。特に $f_{i}=0.357$ を持つ InAs に関しては, その 構造シークエンスの違いは顕著である。すなわち, 結晶 InAs はイオン性物質に特徴的である zincblende 構造から rocksalt 構造への転移を示すの に対し, 液体 InAs は, イオン性の小さな液体に特 徵的である $\beta$-tin 型構造から “ $1 / 2 \beta$-tin $+1 / 2$ bcc” 構 造への構造変化を示す[25]。液体の構造において, 圧力誘起構造変化がイオン性に影響されにくい（よ り大きなイオン性を持つものでないとイオン性液体 的な振る舞いを示さない）理由として，原子配列が 時間的，空間的に乱れている液体においては, rocksalt 構造の様な化学的短距離秩序が必然となる 構造は, 化学的短距離秩序がなくてもよい $\beta$-tinや bcc に比へ, 原子の熱振動, 拡散に伴う化学的短距 離秩序の乱れ（同種イオンの接近）が起こった場合 に，（自由エネルギーの内部エネルギー項の増大の ために）エネルギー的に不安定になりやすいためで あると考えられる。

\section{6. おわりに}

本稿では，四配位共有結合性物質の液体の圧力誘 起構造変化を紹介した。液体の圧力誘起構造変化は, その実験・解析上の困難や得られたデー夕の解釈の 難しさから，長い間ベールに包まれてきた。最近の 高温高圧発生技術の発展, 第三世代放射光源の活用, および計算機の発達により, その姿が現在明かされ つつある。液体に興味を持った若人もしくは結晶に 飽きた（?）先生方が, 本稿をきっかけに液体物理 (Liquid state physics) の道に足を踏み入れてくださ れば，筆者の存外の喜びである。

\section{謝 辞}

これらの内容は, 慶應義塾大学物理学科辻研究室 の辻和彦, 木下智裕, 村岡真輔らとの協同研究の成
果である。本稿に述べた一連の研究は，一人の力で は, 肉体的にも精神的にも到底不可能であり, 多く の方々のご協力を賜りました。ご芳名を記して感謝 の印とさせていただきます。

（敬称略）守哲司，高杉幸伸，多賀尚仁，阿部拓郎， 金原康浩，下原進太郎，鳴島崇，田巻友子，亀卦川 卓美, 片山芳則, 稲村泰弘, 舟越賢一, 船守展正, および家族の皆。

\section{参考文献}

[1] I. Stich, R. Car, M. Parrinello: Phys. Rev. Lett., 63, 2240 (1989).

[2] Y. Waseda, K. Suzuki: Z. f. Physik., B 20, 339 (1975).

[3] V. Petkov, S. Takeda, Y. Waseda, K. Sugiyama: J. Non-Cryst. Solids, 168, 97 (1994).

[4] N. Funamori, K. Tsuji: Phys. Rev. Lett., 88, 255508 (2002).

[5] 守哲司: 慶應義塾大学修士論文 (2001).

[6] 辻和彦: 高圧力の科学と技術, 11, 21 (2000).

[7] J.C. Phillips: in Bonds and Bands in Semiconductors (Academic Press, New York and London, 1973).

[8] R.J. Nelmes, M.I. McMahon: Semicond. and Semimetals, 54, 145 (1998).

[9] A. Mujica, A. Rubio, A. Munroz, R.J. Needs: Rev. Mod. Phys., 75, 863 (2003).

[10] K. Tsuji, K. Yaoita, M. Imai, O. Shimomura, T. Kikegawa: Rev. Sci. Instrum., 60, 2425 (1989).

[11] N. Funamori, K. Tsuji: Phys. Rev. B, 65, 14105 (2001).

[12] T. Hattori, K. Tsuji, N. Taga, Y. Takasugi, T. Mori: Phys. Rev. B, 68, 224106 (2003).

[13] Y. Waseda: in The Structure of Non-Crystalline Materials (McGraw-Hill, New York, 1980).

[14] W. Klement (unpublished).

[15] E. Rapoport: Phys. Rev. Lett., 19, 345 (1967).

[16] T. Hattori, K. Kinoshita, N. Taga, Y. Takasugi, T. Mori, K. Tsuji (submitted).

[17] H. Tanaka: Phys. Rev. E, 62, 6968 (2000).

[18] T. Kinoshita, T. Hattori, T. Narushima, K. Tsuji (submitted).

[19] 木下智裕: 慶應義塾大学修士論文 (2004).

[20] R.J. Nelmes, M.I. McMahon, N.G. Wright, D.R. Allan: Phys. Rev. B, 51, 15723 (1995).

[21] K. Laaziri, S. Kycia, S. Roorda, M. Chicoine, J.L. Robertson, J. Wang, S.C. Moss: Phys. Rev. B, 60, 13520 (1999).

[22] H. Ohno, K. Furukawa: J. Chem. Soc. Faraday Trans. I, 77, 169 (1981).

[23] 村岡真輔: 慶應義塾大学卒業論文 (2004).

[24] 友政雅俊: 慶應義塾大学卒業論文 (2005).

[25] T. Hattori, T. Kinoshita, T. Narushima, K. Tsuji: J. Phys. Condens. Matter, 16, S997 (2004).

[2005 年 2 月 14 日受理] 